\title{
SIMULATING WIND EFFECT ON MICROSPRINKLER WATER DISTRIBUTION
}

\author{
Marco Antônio Fonseca Conceição ${ }^{1 *}$; Rubens Duarte Coelho² \\ ${ }^{1}$ Embrapa Uva e Vinho - Estação Experimental de Jales - C.P. 241 - 15700-000 - Jales, SP - Brasil. \\ ${ }^{2}$ USP/ESALQ - Depto. de Engenharia Rural, C.P. 09 - 13418-900 - Piracicaba, SP - Brasil. \\ *Corresponding author <marcoafc@cnpuv.embrapa.br>
}

\begin{abstract}
Wind incidence can affect microsprinkler water distribution. Evaluations of those conditions can be facilitated using simulations by computational models. The present work evaluates the performance of a ballistic model on simulating the wind effect on microsprinkler water distribution. Experimental tests were carried out using self-compensating microsprinklers, nozzle sizes $1.00 \mathrm{~mm}$ (gray), $1.10 \mathrm{~mm}$ (brown), 1.48 $\mathrm{mm}$ (orange), and $1.75 \mathrm{~mm}$ (yellow). The gray and brown nozzles used black swivels and the orange and yellow nozzles used blue swivels. The wind effect was artificially caused by fourteen $200 \mathrm{~W}$ fans. Computational simulations were realized using SIRIAS software, based on a ballistic model originally developed for sprinkler systems. The correlation coefficients ( $\mathrm{r}$ ) varied from 0.619 to 0.880 , while the exactness coefficients (d) varied from 0.842 to 0.944 . Swivels internal geometry influenced results. Tested models presented performances classified as very good for the black swivel nozzles and regular for the blue swivel nozzles.
\end{abstract}

Key words: irrigation, software

\section{SIMULAÇÃO DO EFEITO DO VENTO NA DISTRIBUIÇÃO DE ÁGUA EM MICROASPERSORES}

\begin{abstract}
RESUMO: A incidência de ventos pode afetar a distribuição da água aplicada por microaspersores. As avaliações nessas condições podem ser facilitadas empregando-se simulações através de modelos computacionais. No presente trabalho avaliou-se o desempenho de um modelo balístico para simular o efeito do vento na distribuição de água em microaspersores. Os ensaios experimentais foram realizados com emissores autocompensantes, com diâmetros de bocais iguais a 1,00 mm (cinza), 1,10 mm (marrom), 1,48 mm (laranja) e $1,75 \mathrm{~mm}$ (amarelo). Os bocais cinza e marrom operaram com rotor preto e os bocais laranja e amarelo utilizaram rotor azul. $\mathrm{O}$ efeito do vento foi provocado artificialmente empregando-se um conjunto de quatorze ventiladores de $200 \mathrm{~W}$ de potência. As simulações computacionais foram realizadas empregando-se o programa SIRIAS, que tem por base um modelo balístico originalmente desenvolvido para sistemas de aspersão convencional. Os coeficientes de correlação (r) variaram de 0,619 a 0,880 , enquanto os coeficientes de exatidão (d) ficaram entre 0,842 e 0,944 . As geometrias internas dos rotores influenciaram os resultados, sendo que o modelo apresentou um classificado como muito bom para os bocais com rotor preto e um desempenho regular para os bocais que trabalharam com rotor azul.

Palavras-chave: irrigação, programa computacional
\end{abstract}

\section{INTRODUCTION}

Wind occurrence can modify microsprinkler water distribution, affecting application uniformity and efficiency (Alves et al., 1997; Dantas Neto et al., 1997; Medeiros et al., 2001). Water distribution evaluation takes time and, frequently, it is not possible to evaluate it at all operational and environmental conditions. The use of mathematical models for computational simulations allows for a more diversified and quick combination of the desired analysis.

Most of the sprinkler water distribution models used to describe drop trajectory under windy conditions are based on ballistic theory. Fukui et al. (1980) presented a model to evaluate water application rate and uniformity coefficient for irrigation systems in windy conditions, considering the overlapping of emitters wetted areas. Seginer et al. (1991) presented a method to simulate sprinkler water distribution under windy condition introducing a $\mathrm{K}$ factor to correct the drag coefficient employed in ballistic models. Similarity between simulated and measured values increased by using this factor.

Tarjuelo et al. (1994) developed a model based on Fukui et al. (1980) and Seginer et al. (1991) methods. However, instead of using Seginer's K factor, the authors employed two other factors $\left(\mathrm{K}_{1}\right.$ and $\left.\mathrm{K}_{2}\right)$ to correct the drag coefficient. The differences between simulated and experimental Christiansen uniformity coefficients (CUC) were lower than $1 \%$ in $40 \%$ of the analyzed cases. 
Microsprinkler irrigation presents operational and hydraulic characteristics similar to sprinkler irrigation. Therefore, simulation models developed for sprinkler systems can be used for microsprinklers. The present study describes the performance of a ballistic model originally developed for sprinkler systems on the simulation of microsprinkler water distribution in windy conditions.

\section{MATERIAL AND METHODS}

Experimental evaluations took place in Piracicaba, SP, Brazil (2242m'30"S; 47³0m'00'W). Self-compensating microsprinklers with swivels were tested, operating with nominal flows of $28 \mathrm{~L} \mathrm{~h}^{-1}$ (gray nozzle), $35 \mathrm{~L} \mathrm{~h}^{-1}$ (brown nozzle), $70 \mathrm{~L} \mathrm{~h}^{-1}$ (orange nozzle) and $95 \mathrm{~L} \mathrm{~h}^{-1}$ (yellow nozzle). Nozzle diameters were 1.00 $\mathrm{mm}, 1.10 \mathrm{~mm}, 1.48 \mathrm{~mm}$ and $1.75 \mathrm{~mm}$, respectively. The gray and brown nozzles used a black swivel, that provided a smaller wet radius, while the others used a blue swivel, which wetted a larger area. The microprinkler was set at $0.38 \mathrm{~m}$ from the soil.

The emitter flows had been measured before each test using the volumetric method. The wind effect was artificially caused by fourteen, $200 \mathrm{~W}$ fans with $0.50 \mathrm{~m}$ of internal diameter, set in two overlayed rows of seven fans. The dispostion of the two rows aimed to force the air of the lower fan row to run over the microsprinkler in a parallel direction to the soil surface, as predicted by the model.

Water distribution was simulated by the use of the software "Simulación de Riego por Aspersión" (SIRIAS), developed by Carrión et al. (2001) on Delphi language for Windows 95, theoretically based on the ballistic model presented by Tarjuelo et al. (1994). The software required as input data the nozzle inclination angle from the horizontal, the operational pressure, the water distribution profile without wind, the environmental conditions and the empirical coefficients $\mathrm{K}_{1}$ and $\mathrm{K}_{2}$, that were adjusted out of laboratory experimental values. $K_{1}$ and $K_{2}$ coefficients were used to modify the spatial water distribution shape caused by the wind effect. Because of the use of pressure compensating microsprinklers, the operational pressures corresponding to the nominal flows were determined from pressureflow curves, obtained without the pressure compensating membrane.

Wind speed was determined using a portable, digital anemometer, with ten registered data at $0.38 \mathrm{~m}$ from the soil on each catch can point. The average speed registered on the microsprinkler distribution profile, parallel to the wind direction, was used as reference. Wind speed variation in relation to the vertical height was calculated by SIRIAS software using the Vories et al. (1987) model. Water distribution was determined using $0.085 \mathrm{~m}$ diameter and $0.13 \mathrm{~m}$ height plastic catch cans, spaced 0.50 $\mathrm{m} \times 0.50 \mathrm{~m}$ and occupying half of the microsprinkler's wetted area, parallel to the wind direction.

To determine the microsprinkler water distribution profiles in no wind conditions, the same plastic catch cans setting as used. The average of three water distribution profiles was used as the correspondent emitter profile. Catch can's collected volumes were determined using graduate recipient with $0.1 \mathrm{~mL}$ precision. Precipitation rates (Ip) were obtained dividing the collected volume by catch can area.

Differences between measured and simulated values were quantified by linear regression determination coefficients $\left(\mathrm{R}^{2}\right)$ and angular coefficients, with curves forced to pass through the axis sistem's origin. A confidence coefficient (c) proposed by Camargo \& Sentelhas (1997), corresponding to the multiplication of the correlation coefficient (r) by the exactness coefficient (d), was also used. The value of (d) can be calculated by the following expression (Willmott et al., 1985, mentioned by Camargo \& Sentelhas, 1997):

$$
\mathrm{d}=1-\left[\Sigma(\mathrm{Pi}-\mathrm{Oi})^{2} / \Sigma(|\mathrm{Pi}-\mathrm{O}|+|\mathrm{Oi}-\mathrm{O}|)^{2}\right]
$$

where $(\mathrm{Pi})$ are the simulated values, $(\mathrm{Oi})$ are the measured values and $(\mathrm{O})$ is the average of the measured values.

To evaluate data performance in relation to the confidence coefficient (c), a scale based on Camargo \& Sentelhas (1997), with alterations, was used. The performance was classified as excellent for (c) values higher than 0.85 ; as very good for values between 0.76 and 0.85 ; as good for values between 0.66 and 0.75 ; as regular for values between 0.51 and 0.65 ; as bad for values between 0.41 and 0.50 ; and as very bad for values lower than 0.40 .

To compare the simulation results with those obtained by Tarjuelo et al. (1994) using sprinklers, the differences between measured and simulated values were also determined using the following expression used by the authors:

$$
\mathrm{D}=\left(\mathrm{S} / \mathrm{N}_{0}\right)^{1 / 2} /\left(\mathrm{Q} / \mathrm{A}_{0}\right)
$$

where (D) is the total difference between measured and simulated values; (S) is the sum of the square of the differences between simulated and measured values in each point; (No) is the number of wet points; Q is emitter total flow; and Ao is the emitter wetted area under no wind condition.

\section{RESULTS AND DISCUSSION}

Wind speed at $0.38 \mathrm{~m}$ height presented an average value of $3.2 \mathrm{~m} \mathrm{~s}^{-1}$. This value corresponds to, approximately, $7.1 \mathrm{~m} \mathrm{~s}^{-1}$ for $2.0 \mathrm{~m}$ height from soil, according to 
equation 1 used in SIRIAS. Water was not collected in the catch cans at distances exceding $1.5 \mathrm{~m}$ from the microsprinkler in opposition to wind direction.

SIRIAS software calculated the evaporation and drift losses (EDL) using a multiple regression model developed by the authors, obtaining EDL from air relative humidity, air temperature and wind speed. However, the model strongly underestimated EDL when comparing with experimental data, because the essays took place in different operational conditions in relation to the original conditions. As it was not possible to modify software's EDL procedure, the experimental EDL values were used to run the simulations. Those values corresponded to $21.4 \%, 17.1 \%, 30.2 \%$ and $24.2 \%$ for gray, brown, orange and yellow nozzle, respectively.

Gray and brown nozzles EDL values are in the same level of the values registered by Alves et al. (1997), who obtained EDL varying from $12.1 \%$ to $21.2 \%$ for microsprinkler at $0.30 \mathrm{~m}$ from the soil surface and wind speed between $0.53 \mathrm{~m} \mathrm{~s}^{-1}$ and $2.58 \mathrm{~m} \mathrm{~s}^{-1}$. However, blue swivel nozzles presented losses higher than those registered by Alves et al. (1997).

Empirical $\mathrm{K}_{1}$ and $\mathrm{K}_{2}$ values were obtained from correlations between measured and simulated spatial water distribution data, selecting the $\mathrm{K}_{1}$ and $\mathrm{K}_{2}$ values that resulted in the highest determination coefficients $\left(\mathrm{R}^{2}\right)$. After testing different combinations, the best $\left(\mathrm{R}^{2}\right)$ values were obtained for $\mathrm{K}_{1}$ and $\mathrm{K}_{2}$ equal zero.

Because regression curves were forced to pass by the origin, the angular coefficients reflected the adjustment between measured and simulated values. The closer those coefficients were to 1.00 , the better the adjustment of the model to experimental data. The highest determination coefficients $\left(\mathrm{R}^{2}\right)$ and angular coefficients were observed for nozzles which used black swivels (gray and brown) in comparison to those which used blue swivels (Figure 1).

Measured water distribution in windy conditions presented abrupt ruptures in the four opposite sides, while the simulated distributions presented higher symmetries and reached higher distances from the microsprinkler (Figure 2). The main reason for this behavior is the fact that in the model, the wind speed does not vary with the distance while in the essays the wind speed presented a reduction proportional to the fan distance, what produced the mentioned rupture. In those disrupted areas were observed many measured values equal zero with the respective simulated values different of zero, and that affected the regression model (Figure 1).

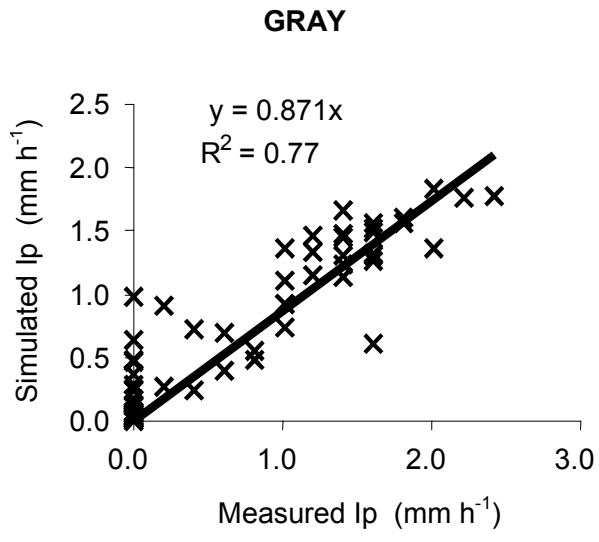

ORANGE

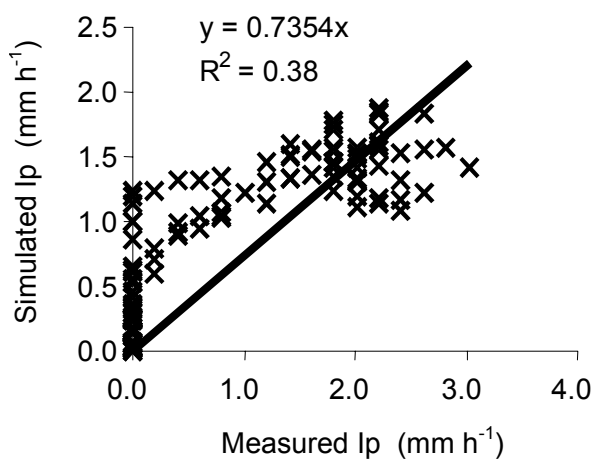

BROWN

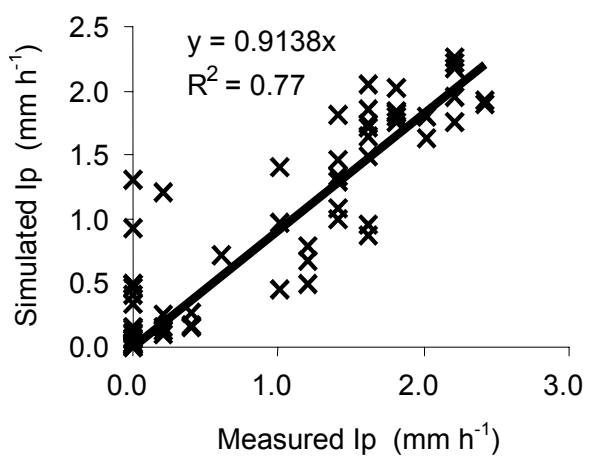

YELLOW

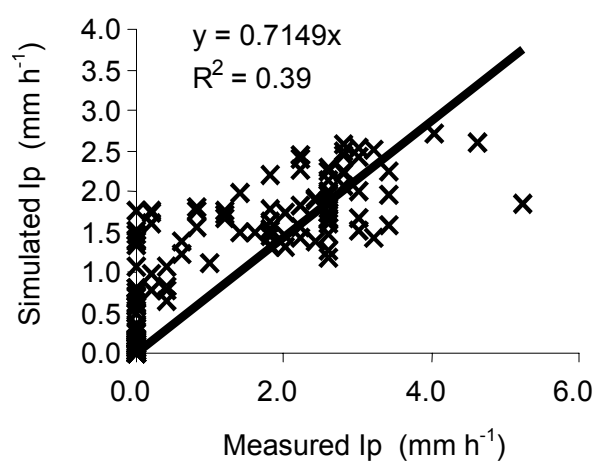

Figure 1 - Relationship between measured and simulated precipitation rates (Ip) for different microsprinkler nozzles. 
The turbulent wind flux also was a differentiation factor between simulated and measured data. The mathematical model considers that the wind direction is parallel to the soil surface, what does not occur in experimental conditions, where exist vertical fluxes beside of the lateral fluxes. The circular shape of the simulated water distributions resulted from the use of $\mathrm{K}_{1}$ and $\mathrm{K}_{2}$ coefficients equal zero.

The exactness (d) and correlation (r) coefficients presented higher values for the black swivel nozzles (gray and brown) in comparison to the blue swivel nozzles (Table 1). Multiplying (d) by (r) results on confidence coefficient (c) that reflects the model performance. For black swivel nozzles the performances were classified as very good while for the blue swivel nozzles the performances were classified as regular (Table 1).
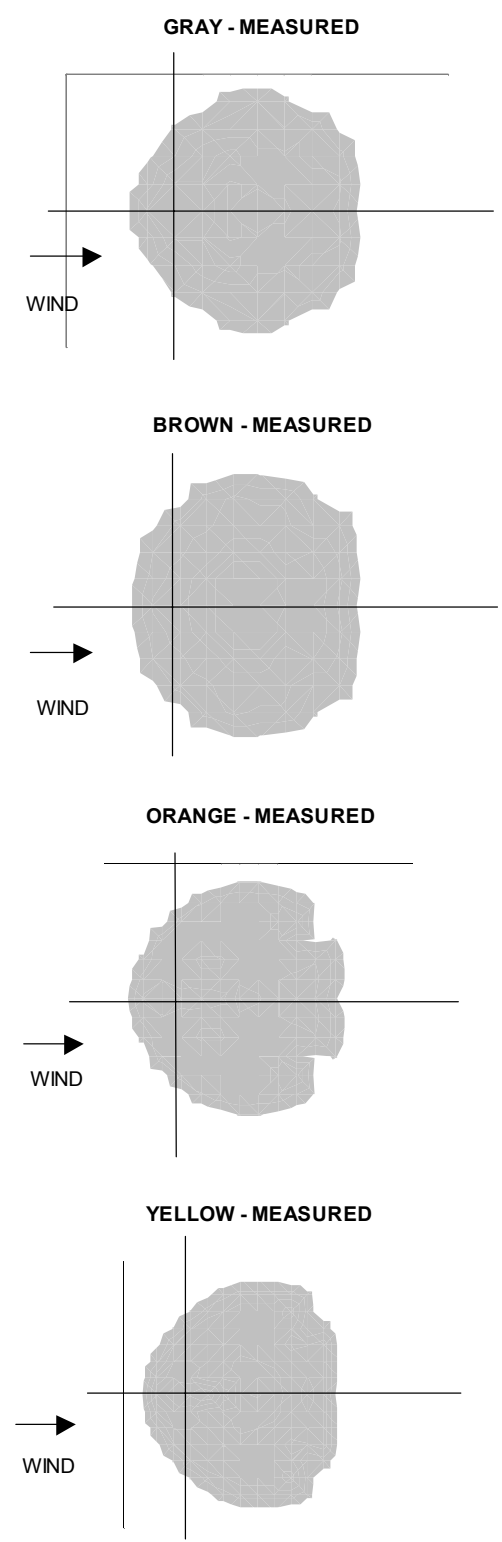

Those results accentuate the importance of swivel internal geometry on the simulations. This input variable was not considered by the model but directly affected its performance. It is necessary, therefore, to include this variable in the development of future swivel emitter models.

Table 1 - Exactness (d), correlation (r) and confidence (c) coefficients and performance classification for different nozzles.

\begin{tabular}{lcccc}
\hline Nozzle & $\mathrm{d}$ & $\mathrm{r}$ & $\mathrm{c}$ & Performance \\
\hline Gray & 0.943 & 0.880 & 0.830 & Very Good \\
Brown & 0.944 & 0.880 & 0.831 & Very Good \\
Orange & 0.849 & 0.619 & 0.525 & Regular \\
Yellow & 0.842 & 0.628 & 0.529 & Regular \\
\hline
\end{tabular}
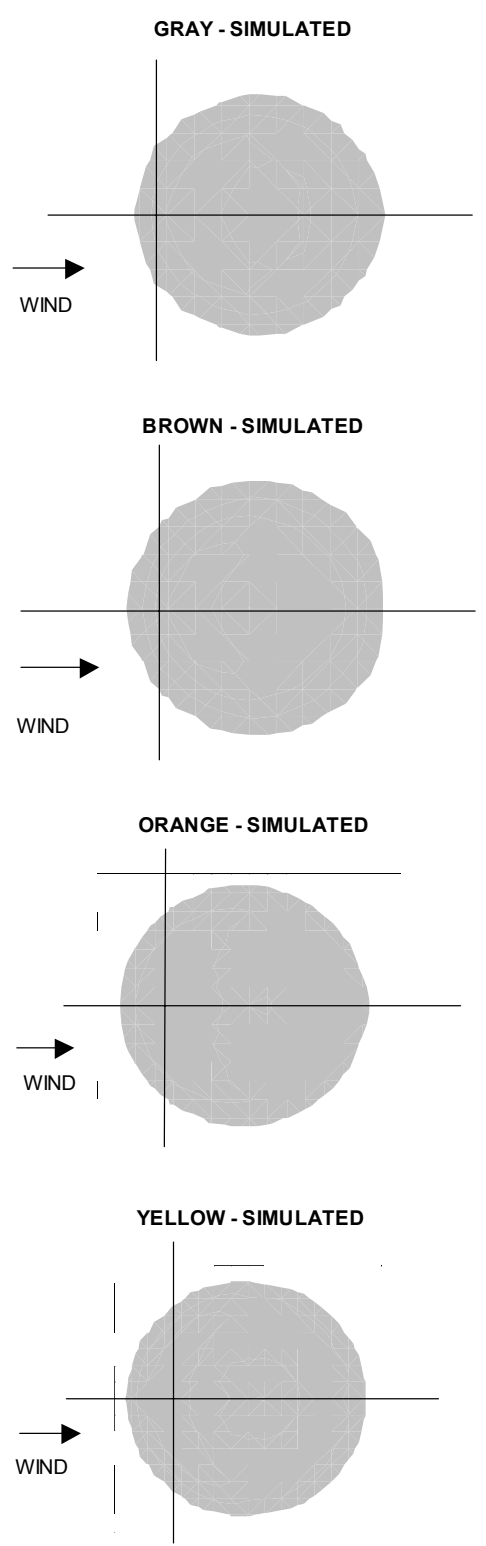

Figure 2 - Measured and simulated precipitation rates (Ip) of spatial water distributions of different microsprinkler nozzles in windy condition. 
The normalized differences values (D) between measured and simulated water distribution were 0.30 , $0.31,0.41$ and 0.44 for gray, brown, orange and yellow nozzles, respectively. Tarjuelo et al. (1994), using the same model on evaluating sprinkler systems, found D values between 0.32 and 0.63 for wind speed between 3.20 $\mathrm{m} \mathrm{s}^{-1}$ and $5.75 \mathrm{~m} \mathrm{~s}^{-1}$. In such case, microsprinkler simulation presented analogous performance as the obtained by Tarjuelo et al. (1994) for sprinkler systems.

Tarjuelo et al. (1994) also used Christiansen uniformity coefficient (CUC) to evaluate the simulation performance of the model on overlapping of sprinkler wetted areas. The differences between measured and simulated CUC values were always lower than $10 \%$, what represents a satisfactory performance. If microsprinkler D values were at the same magnitude of the sprinklers $D$ values, it can be deduced that the differences of microsprinkler overlapping CUC values could be as low as the sprinkler data obtained by Tarjuelo et al. (1994).

The ballistic model of Tarjuelo et al. (1994) was specially developed to simulate CUC values to be used to study the overlapping of sprinkler water distribution in windy conditions. The adjusted model could be used, for instance, to determine the best space between sprinklers which enables higher application uniformity in windy conditions. For this reason its performance is reduced when it is used to evaluate water distribution by an isolated emitter.

\section{ACKNOWLEDGMENT}

To Dr. Jesús Montero Martinez for send us the SIRIAS software; and to Dr. Fátima Conceição Rezende and Dr. Wellington Farias Araújo for the suggestions and support on the experimental tests.

\section{REFERENCES}

ALVES, E.F.; LEÃO, M.C.S.; CASTRO, P.T. de. Qualidade de irrigação de um microaspersor em diferentes alturas de instalação e velocidade média de vento na região do Vale do Curu. (compact disc). In: CONGRESSO BRASILEIRO DE ENGENHARIA AGRÍCOLA, 26., Campina Grande, 1997. Anais. Campina Grande: SBEA, 1997.

CAMARGO, A P. de; SENTELHAS, P.C. Avaliação do desempenho de diferentes métodos de estimativa da evapotranspiração potencial no Estado de São Paulo, Brasil. Revista Brasileira de Agrometeorologia, v.5, p.89-97, 1997.

CARRIÓN, P.; TARJUELO, J.M.; MONTERO, J. SIRIAS: a simulation model for sprinkler irrigation. I. Description of the model. Irrigation Science, v.20, p.73-84, 2001.

DANTAS NETO, J.; MEDEIROS, M.G.A. de; AZEVEDO, C.A.V. de; AZEVEDO, H.M. de. Performance hidráulica e perfil de distribuição de água do microaspersor NAAN 7110, sob diferentes condições de vento. Revista Brasileira de Engenharia Agrícola e Ambiental, v.1, p.57-61, 1997.

FUKUI, Y.; NAKANISHI, K.; OKAMURA, S. Computer evaluation of sprinkler irrigation uniformity. Irrigation Science, v.2, p.23-32, 1980.

MEDEIROS, M.G.A.; MATOS, J. de A.; AZEVEDO, C.A.V. de; DANTAS NETO, J. Influência de fatores climáticos na eficiência potencial de aplicação de água do microaspersor Naan 7110 em condições de campo. In: CONGRESSO BRASILEIRO DE ENGENHARIA AGRÍCOLA, 27. Lavras, 1998. Anais. Lavras: UFLA;SBEA, 2001. v.2, p.142-144.

SEGINER, I.; NIR, D.; von BERNUTH, R. D. Simulation of wind-distorted sprinkler patterns. Journal of Irrigation and Drainage Engineering, v.117, p.285-306, 1991.

TARJUELO J.M.; CARRION, P.; VALIENTE, M. Simulación de la distribución del riego por aspersión en condiciones de viento. Investigación Agraria: Producción e Protección Vegetal, v.9, p.255271, 1994.

VORIES, E. D.; von BERNUTH, R. D.; MICKELSON, R. H. Simulating sprinkler performance in wind. Journal of Irrigation and Drainage Engineering, v.113, p.119-130, 1987. 